\title{
FORMATION OF THE TIMETABLE FOR THE SUPPLY OF RAW MATERIALS TO THE SUGAR FACTORY WITH THE USE OF GENETIC ALGORITHMS
}

\author{
S. Makovetska, O. M'yakshylo \\ National University of Food Technologies
}

\begin{tabular}{l}
$\quad$ Key words: \\
Properties of sugar beet \\
hybrids \\
Raw area \\
Seasonal production \\
Genetic algorithm \\
Individual structure \\
MatLab \\
\hline
\end{tabular}

Article history:

Received 09.01.2018

Received in revised form

24.01.2018

Accepted 14.02.2018

Corresponding author:

S. Makovetska

E-mail:

npnuht@ukr.net

\begin{abstract}
The effectiveness of sugar production largely depends on the technological quality of raw material - sugar beet. When sugar beets with the same sugar content are processed at different sugar beet plants, the yield of sugar largely fluctuates, that is, the technological qualities of the sugar beet roots of these batches were different, which is determined by the genetically determined properties of individual varieties and sugar beet hybrids. As a result of the analysis of sugar production functioning, it can be concluded that applying the correct selection of modern highyield sugar beet varieties and hybrids with high technological parameters and their processing time at the sugar factory, one of the additional reserves to increase the efficiency of sugar production can be obtained. Therefore, when planning the supply of raw materials to a sugar plant, it is necessary to examine the genetically determined properties of modern varieties and sugar beet hybrids.

The paper considers the problem of the process of forming an effective schedule for the supply of raw materials from various raw material zones to the sugar factory to ensure a reduction in production costs, taking into account the genetically determined properties of modern varieties and sugar beet hybrids and the seasonality of production. The task of forming an effective schedule for the supply of raw materials from various raw material zones to the sugar plant to ensure a reduction in production costs and increase the technical and economic indicators of production belongs to the class of NP-complete combinatorial problems. Taking into account the specific features of the problem under constant economic and climatic changes, it requires the constant adjustment of the plan for the import of raw materials to the sugar factory and a significant amount of data, the use of traditional methods to solve this task is impossible. Therefore, it is advisable to use heuristic methods to solve such problems.

The article suggests a modern optimization method based on heuristic approaches - genetic algorithm. As a result of the implementation of the genetic algorithm in MatLab, a software module was created, taking into account the structure of the individual and the function of fitness.
\end{abstract}

DOI: $10.24263 / 2225-2924-2018-24-1-3$ 


\title{
ФОРМУВАННЯ РОЗКЛАДУ ПОСТАВОК СИРОВИНИ НА ЦУКРОВИЙ ЗАВОД IЗ ЗАСТОСУВАННЯМ ГЕНЕТИЧНИХ АЛГОРИТМІВ
}

\author{
С.В. Маковецька, О.М. М'якшило \\ Національний університет харчових технологій
}

Ефективність иукрового виробництва значною мірою залежсть від технологічної якості сировини - цукрового буряка. При переробці на иукрових заводах різних партій буряків з однаковою иукристістю вихід иукру значною мірою коливається, тобто технологічні якості коренеплодів иукрових буряків цчих партій були різними, щзо обумовлено генетико-детермінованими властивостями окремих сортів $і$ гібридів цукрового буряка. В результаті аналізу функціонування цукрового виробництва можна зробити висновок, щзо, застосовуючи правильний підбір сучасних високопродуктивних сортів $i$ гібридів цукрових буряків з високими технологічними показниками і термінами ïx перероблення на иукровому заводі, можна отримати один із додаткових резервів підвищення ефективності виробництва иукру. Тому при плануванні постачання сировини на иукровий завод необхідно обов'язково враховувати генетико-детерміновані властивості сучасних сортів і гібридів иукрових буряків.

У статті розглядається проблема процесу формування ефективного розкладу постачання сировини з різних сировинних зон на иукровий завод для забезпечення скорочення виробничих витрат з урахуванням генетико-детермінованих властивостей сучасних сортів $і$ гібридів иукрових буряків та сезонності виробництва. Задача формування ефективного розкладу постачання сировини з різних сировинних зон на иукровий завод для забезпечення скорочення виробничих витрат і підвищення техніко-економічних показників виробництва відноситься до класу NP-повних комбінаторних задач. Оскільки особливості задачі специфічні за умови постійних економічних і кліматичних змін, що вимагає постійного коригування плану завезення сировини на цукровий завод та значної кількості даних, то використання традиційних методів для розв'язання неможливе. Тому для розв'язку таких задач доцільно використовувати евристичні методи.

Авторами запропоновано сучасний метод оптимізащї, щзо базується на евристичних підходах — генетичний алгоритм. У результаті реалізації генетичного алгоритму в середовищі MatLab було створено програмний модуль з урахуванням структури індивіда та функиії пристосованості.

Ключові слова: властивості гібридів цукрових буряків, сировинна зона, сезонність виробництва, генетичний алгоритм, структура особини, MatLab.

Постановка проблеми. Цукровий буряк - основна сировинна для цукрового заводу, яка має тенденцію швидко втрачати свої якості (цукристість і тургор) і саме через цю особливість виникає потреба слідкувати за графіком збирання та вивезення сировини із сировинних зон цукрового за- 
воду. Сировина, яка не відповідатиме технологічним характеристикам при переробці, буде мати невеликий вихід готової продукції - цукру.

Цукровий завод, що має добре організовані сировинні зони, отримує сировину для переробки більш високої якості, яка надходить у ритмічному режимі і в оптимальні терміни. Підприємство при цьому несе менші витрати, пов’язані з доставкою, краще використовує виробничі потужності, матеріальні і трудові ресурси, має більш високі техніко-економічні показники порівняно $з$ підприємствами, у яких сировинні зони організовані невдало.

Використовуючи правильний підбір сучасних гібридів цукрових буряків i терміни їх надходження на цукровий завод, навіть при однаковій собівартості одиниці вирощеної сировини, на етапі іï переробки на цукровому заводі можна отримати значний додатковий економічний ефект.

Отже, для отримання максимальних техніко-економічних показників цукрового виробництва необхідно організувати ефективне постачання сировини на завод 3 конкретних сировинних зон для забезпечення безперервного, ритмічного виробничого процесу 3 мінімальними виробничими витратами для кожної партії цукрових буряків. Реалізувати таке завдання без використання інформаційних технологій неможливе, тому доцільно скористатися одним із перспективних евристичних методів - генетичним алгоритмом, який є потужним інструментом оптимізації.

Аналіз останніх досліджень і публікацій. Результат роботи цукрового заводу цілком залежить від технологічної якості цукрового буряка, зокрема від генетико-детермінованих властивостей кожного типу гібриду та оптимізації постачання сировини на бурякоприймальні пункти. Зокрема, в публікації [1] розглядається впровадження у виробництво нових гібридів цукрового буряка, що характеризуються більш високим потенціалом продуктивності та дають змогу підвищити отримання цукру з гектара посівів.

У [2] розглядається раціональна організація матеріально-технічного постачання цукрових заводів, також обгрунтовано комплекс заходів 3 оптимізації постачання сировини, що сприятиме скороченню виробничих витрат і підвищенню економічної ефективності виробництва цукру за рахунок формування системи партнерських відносин між цукровими заводами та постачальниками цукрових буряків і зниження, на цій основі, ризиків виникнення кризових ситуацій.

Для раціонального функціонування промислового підприємства і планування випуску продукції виникає необхідність у формуванні розкладу. В публікації [3] розглядається задача складання розкладу для виробництва, де необхідно враховувати навантаження, зберігання і транспортування продуктів на виробництві. Часто на підприємствах виникає необхідність у створенні розкладу, де для виконання виробничих операцій потрібно враховувати різного роду обмеження ресурсів (сировина, електроенергія, людські ресурси тощо). Вирішення таких задач в рамках декомпозіційного підходу розглянуто в [4].

Проте в розглянутих публікаціях не висвітлено питання забезпечення підприємства сировиною 3 урахуванням ii технологічної якості, терміну 
дозрівання, що є резервом для підвищення техніко-економічних показників виробництва.

Мета дослідження: формування ефективного розкладу поставок сировини на цукровий завод, що дасть змогу скоротити втрати цукру та підвищити техніко-економічні показники виробництва 3 використанням евристичного методу — генетичного алгоритму.

Викладення основних результатів дослідження. Цукрове виробництво складний комплекс, що поєднує різні процеси як сільськогосподарського, так i промислового характеру (вирощення цукрового буряку, його транспортування й технологічного циклу переробки в готовий продукт).

Вплив сировинного фактора на рівень ефективності цукробурякового виробництва виражається в тому, що, по-перше, кількість і якість буряка, який переробляється, впливають на ефективність виробництва цукру; по-друге, специфічні особливості коренеплодів цукрового буряка, що виражаються у високому вмісті вологи (75-80\%), обумовлюють їх швидке псування, малотранспортабельність, а також високі витрати на виробництво одиниці готової продукції. Тому при переробці коренеплодів цукрового буряка отримуємо невеликий вихід готової продукції, а зворотна величина - витрата сировини на одиницю готової продукції - досягає дуже високих показників.

Як зазначається в [5], одним із основних напрямів підвищення ефективності виробництва цукру є отримання високоцукристої, технологічно якісної та зрілої сировини. Технологічна якість і зрілість сировини обумовлена хімічним складом іiі коренеплодів, насамперед максимальною наявністю в ній цукру, що найбільшою мірою впливає на показники виходу готового продукту, а також на наявність у буряках мелясоутворюючих компонентів нецукрів, що перешкоджають вилученню цукру.

На разі у буряківництві України впроваджуються сучасні сорти і гібриди різного селекційного походження. У процесі селекції створено сорти з різним рівнем цукристості коренеплодів, показники яких лягли в основу розподілення сортів на три напрями - врожайного $(E)$, нормального $(N)$, цукристого $(Z)$. Відповідно до їхніх генетичних характеристик коренеплоди різняться між собою врожайністю, вмістом цукру, а також терміном достигання та зберігання.

Кожен сорт і гібрид цукрового буряка, залежно від його генетико-детермінованих властивостей i впливу факторів зовнішнього середовища, втрачає свою технологічну якість, що суттєво відбивається на економічних показниках підприємства й обумовлює сезонність виробництва як одну 3 характерних особливостей цукрової промисловості [6]. Тож, одним із головних завдань цукровиробництва є організація ефективного постачання сировини на завод із конкретних сировинних зон для забезпечення безперервного виробничого процесу з максимальним виходом цукру.

Авторами було проведено дослідження та математичне моделювання процесу постачання цукрових буряків з урахуванням їх генетико-детермінованих властивостей на цукровий завод. Розроблена математична модель охоплює всі аспекти процесу планування постачання сировини для іï переробки 3 
метою скорочення втрат цукру та підвищення техніко-економічних показників підприємства [7].

Задача формування ефективного розкладу постачання сировини з різних сировинних зон на завод для забезпечення скорочення виробничих втрат відноситься до NP-повних комбінаторних задач [8]. Вирішення даної задачі за умови значної кількості даних 3 використанням точних методів не $\epsilon$ можливим, використання евристичних методів призводить до значних часових витрат, пов'язаних з високою обчислювальною складністю при формуванні рішення та великої ймовірності відхилення знайденого рішення від оптимального [9]. Тому для задач такого класу доцільно використовувати евристичні методи, які дозволяють знайти оптимальний розв'язок задачі за короткий проміжок часу.

Одним iз перспективних евристичних методів $є$ генетичні алгоритми. Генетичні алгоритми - це потужний інструмент оптимізації. За своєю природою вони працюють із сукупністю індивідів, виконуючи паралельний пошук, легко можуть бути реалізовані на паралельних архітектурах, що дає змогу значно підвищити швидкість пошуку та якість отриманих рішень.

При реалізації генетичного алгоритму необхідно розробити структуру індивіда. До нього висуваються такі вимоги:

- індивід несе всю необхідну інформацію розв'язку задачі, тобто варіант розкладу поставок цукрових буряків на цукровий завод;

- за індивідом можна відносно легко розрахувати функцію придатності, тобто зважений показник якості розкладу поставок.

Розглянемо структуру індивіда: введемо набор визначень. Ресурс - це кожний з об'єктів, для яких складається розклад. Є чотири типи ресурсів: $C_{i}$ - вміст цукру в цукрових буряків, що надходять $3 i$-ї сировинної зони; $Z_{i}$ - коефіцієнт забрудненості цукрових буряків $3 i$-ї сировинної зони; $T r_{i}$ — витрати на транспортування цукрових буряків $3 i$-ї сировинної зони на приймальний пункт цукрового заводу; $x_{i j}$ - обсяг поставок відповідного гібриду цукрового буряка $3 i$-ї сировинної зони, за кожну $j$-декаду надходження за весь період роботи цукрового заводу.

Подія - це кортеж, що містить по одному об'єкту кожного 3 типів ресурсів. Для кожної події точно відомі декада постачання сировини на завод, тип гібриду та зони постачання. Цукристість гібридів та обсяг повинні бути назначені в процесі пошуку оптимального розв'язку серед множини припустимих розв'язків.

При реалізації генетичного алгоритму потрібно розробити функцію оцінювання придатності. Для регулювання роботи генетичного алгоритму було впроваджені такі функції пристосованості [7]:

1. Для забезпечення оптимальної роботи цукрового заводу на початку сезону необхідно сформувати запас сировини на період від $N$ до $M$ діб:

$$
N \cdot P \leq \sum_{j=1}^{t_{i}} \sum_{i=1}^{k}\left(x_{i j}\right) \leq M \cdot P,
$$


де $N-9$-денний запас; $M-15$-денний запас цукрового буряка; $P-$ добова потужність цукрового заводу, де $x_{i j}$ - обсяг постачання цукрових буряків 3 $i$-ї сировинної зони, за кожний $j$ - декада надходження за весь період роботи цукрового заводу $\left(j=1 \ldots t_{i}\right.$, від першої до останньої $\left(t_{i}\right)$ декади роботи надходження 3 -ї сировинної зони); $Z_{i}-$ коефіцієнт забрудненості коренеплодів цукрових буряків $3 i$-ї сировинної зони; $C_{i}-$ вміст цукру (дигестія) із коренеплодів цукрового буряка, що надходять $3 i$-ї сировинної зони $(i \in 1 \ldots k) ; k-$ кількість сировинних зон, з яких надходить цукровий буряк. 3 огляду на характеристики заводу значення параметрів періоду запасів цукрового буряку може бути змінено.

2. Постачання буряків 3 урахуванням біологічних термінів збирання гібридів коренеплодів на завод:

- для ранньостиглих гібридів: $\sum_{\tau=1}^{9} C_{\text {гиб, },} X_{y}=R_{y}$;

- для середньостиглих гібридів: $\sum_{\tau=2}^{9} C_{\text {гиб, },} X_{y}=R_{y}$;

- для гібридів нормального типу: $\sum_{\tau=3}^{9} C_{\text {гиб, } y} X_{y}=R_{y}$,

де $C_{\text {гиб, }, y}$ - цукристість буряка; $R_{y}$ - обсяг цукрових буряків даного типу; $\tau-$ декади дозрівання гібридів цукрового буряку (в межах від першої декади вересня до дев'ятої - останньої декади листопада); $X_{y}$ - сумарний обсяг переробленого буряка відповідного гібриду.

У табл. 1 представлено постановку задачі для складання оптимального плану поставки сировини на цукровий завод на основі генетичного алгоритму.

Таблиия 1. Постановка задачі для складання оптимального плану поставки сировини на цукровий завод

\begin{tabular}{|c|c|c|c|c|c|}
\hline Педуії & $\begin{array}{c}\text { Поставки від } \\
\text { 1-го поста- } \\
\text { чальника } \\
\text { за } 1 \text { декаду }\end{array}$ & $\begin{array}{c}\text { Поставки від } \\
\text { 2-го поста- } \\
\text { чальника } \\
\text { за } 1 \text { декаду }\end{array}$ & $\begin{array}{c}\text { Поставки від } \\
\text { 3-го поста- } \\
\text { чальника } \\
\text { за1 декаду }\end{array}$ & $\ldots$ & $\begin{array}{c}\text { Поставки від } \\
\text {-го поста } \\
\text { чальника } \\
\text { за } j \text { декаду }\end{array}$ \\
\hline $\begin{array}{c}\text { Цукристість } \\
\text { гібриду }\end{array}$ & Ген 1,1 & Ген 1,2 & Ген 1,3 & $\ldots$ & Ген $1, n$ \\
\hline $\begin{array}{c}\text { Обсяг постачання } \\
\text { гібриду }\end{array}$ & Ген 2,1 & Ген 2,2 & Ген 2,3 & $\ldots$ & Ген $2, n$ \\
\hline $\begin{array}{c}\text { Транспортні } \\
\text { витрати }\end{array}$ & Ген 3,1 & Ген 3,2 & Ген 3,3 & $\ldots$ & Ген $3, n$ \\
\hline $\begin{array}{c}\text { Коефіціснт } \\
\text { забрудненості }\end{array}$ & Ген 4,1 & Ген 4,2 & Ген 4,3 & $\ldots$ & Ген $4, n$ \\
\hline
\end{tabular}

Життєвий цикл популяції - це декілька випадкових схрещувань (за допомогою кросовера ) і мутації. Після цих дій до популяції додаються нові індивідууми. Вибір у генетичному алгоритмі - процес формування нової популяції на основі старої та відмирання старої популяції. В результаті 
відбору до нової популяції знову застосовуються операції кросовера і мутації та відбувається відбір тощо.

Розклад - це множина подій. Об'єкти деяких подій тривіально залежать від об’єктів іншої події. Наприклад, цукрові буряки різних видів гібридів мають однакові показники цукристості, але мають різні терміни дозрівання, тому необхідно занести ці пов'язані події в різні декади.

Нетривіальні вимоги до розкладу будемо задавати за допомогою часткових штрафних функцій (постачання цукрових буряків від $i$-го господарства пізніше зазначеної дати, надходження цукрового буряка не в повному обсязі). Кожна 3 цих функцій співвідносить розкладу не негативне число. Штрафні функції задають жорсткі вимоги, виконання яких обов'язкове для припустимих розкладів.

Кожен індивід має чотири хромосоми. Кожна хромосома відповідає типу ресурсу і містить стільки генів, скільки є подій. Генетичний алгоритм змінює гени лише тих хромосом, які відповідають змінним ресурсам (тобто цукристість гібридів та обсяг постачання), тому перші дві хромосоми можна зберігати в одному екземплярі для всієї популяції. Загалом потрібно зберігати $2 n+$ $+2 n p$ генів, де $p$ - кількість особин в популяції. Цю структуру можна поліпшити. Залежні ресурси можна не зберігати в особині, тому що вони однозначно розраховуються через незалежні ресурси. Нова структура включає одну особину, що зберігає лише незалежні гени, тому потрібно зберігати $2 n+n p$ генів.

На ефективність алгоритмів впливатимуть параметри: початкова популяція, стратегія уточнення цільової функції, рівень мутацій, рівень схрещувань, стратегія відбору, об'єм популяції, стратегія формування нової популяції, локальний пошук і специфічні оператори, кількість обчислювальних елементів.

Математична модель оптимізації поставок цукрового буряку на цукровий завод на основі цільової функції має вигляд [7]:

$$
f=\sum_{j=1}^{t_{i}} \sum_{i=1}^{k}\left(x_{i j}-x_{i j} \cdot Z_{i}\right) \cdot C_{i}-\sum_{j=1}^{t_{i}} T r_{i} \rightarrow \max .
$$

Цільова функція (3) відповідає основній меті функціонування цукрового заводу, а саме: забезпечити максимальний вихід цукру із сировини, що надійшла на завод.

На основі проведеного дослідження було створено декілька програмних модулів в середовищі MatLad, в яких описуються відповідні функції:

- Sugarbeet_scheme - головний модуль програми, має великий функціонал, але при цьому використано та залишено лише необхідні елементи;

- CheckTransport - обрахування доцільності транспортування буряка із зони;

- CheckVolume - перевірка на величину обсягу поставки буряка із зони;

- CheckWarehouse - перевірка на допустимість відносно об'єму складу;

- Fetus - створення першого нащадка для подальших модифікацій;

- Hybrid - відтворення гібриду для наступного покоління;

- Mutant - модуль, у якому відбувається процес мутації;

- Sort - сортування поколінь за спаданням та безпосереднє заміщення. 
У модулі «Sugarbeet_scheme» використано метод кластеризації стосовно процесу роботи самого алгоритму, а саме: метод двохетапної роботи генетичного алгоритму. В цьому методі відбувається відбір еліти $(N-$ кількість особин в одному поколінні; $m$ - кількість еліти, що обирається 3 кожного покоління) та продовжується робота тільки з нею.

У результаті застосування оператора мутації (модуль «Mutant») формується популяція нащадків, що замінює батьківську популяцію, після чого виконується перевірка умови зупинки алгоритму. Якщо задане значення максимальної кількості ітерацій алгоритму досягнуто, то алгоритм завершує роботу. В останньому поколінні як розв'язок задачі вибирається той варіант розкладу, який найбільшою мірою задовольняє вимоги, що ставляться до розкладу.

Нижче наведено код модуля «Mutant» (рис. 1):

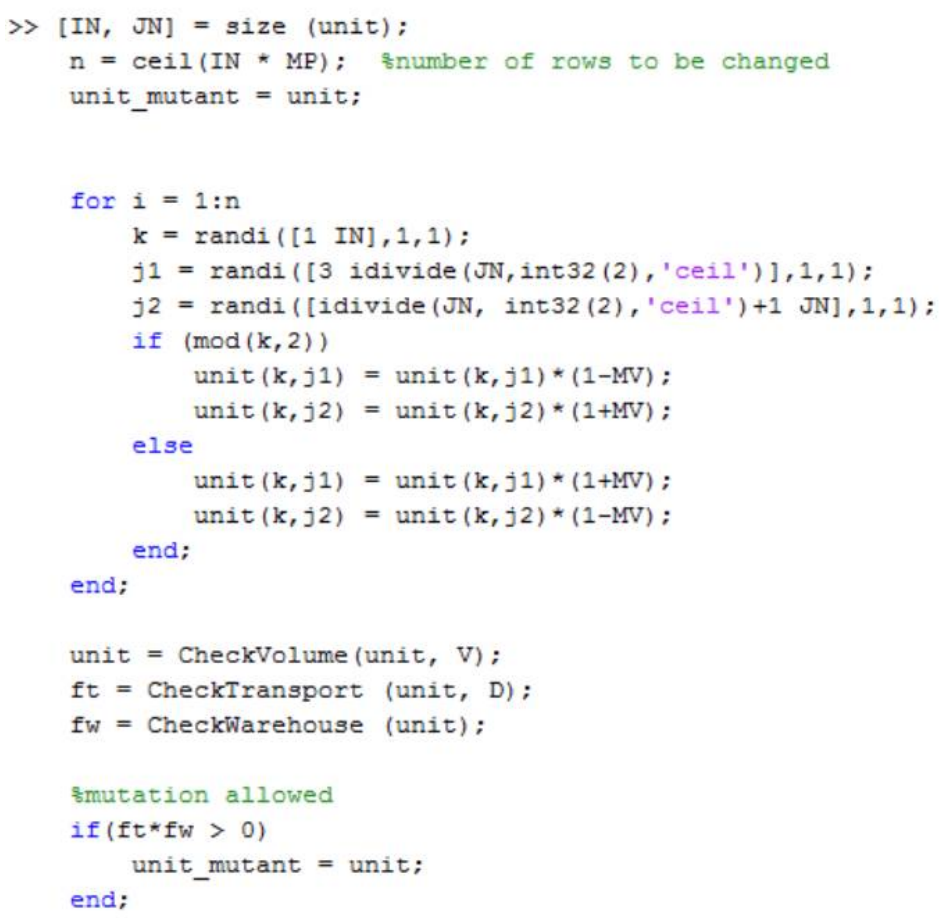

Рис. 1. Реалізація оператора мутації в середовищі MatLab

При реалізації генетичного алгоритму був використаний метод розпаралелювання, який заснований на використанні засобу MatLab Parallel Computing Toolbox i представлених модулів, що дає змогу збільшити швидкість роботи алгоритму.

Результат роботи генетичного алгоритму — розклад поставки сировини на цукровий завод (рис. 2) організовано у середовищі засобу Microsoft Excel. У ньому доступна така інформація:

- параметри, за якими відбувалася побудова генетичного алгоритму; 
- значення функції, що було знайдено, яке відповідає найбільшій можливій величині отриманої продукції;

- якому поколінню відповідає отриманий результат;

- назви відповідних гібридів, стосовно яких виконувалися розрахунки;

- декади, протягом яких буде здійснюватися збір відповідних гібридів цукрового буряка на сировинних зонах для постачання на цукровий завод;

- назви сировинних зон, на яких вирощується цукровий буряк;

\begin{tabular}{|c|c|c|c|c|c|c|c|c|c|c|}
\hline & \multirow{3}{*}{\multicolumn{2}{|c|}{$\begin{aligned} \mathrm{GN} & =100 \\
\text { Fmax } & =3542429,3 \\
\text { коління } & =96\end{aligned}$}} & \multirow[t]{3}{*}{$m=5$} & & \multicolumn{2}{|c|}{$\mathrm{N}=30$} & \multicolumn{2}{|c|}{$\mathrm{MP}=0,2$} & \multicolumn{2}{|c|}{$\mathrm{MV}=0,25$} \\
\hline & & & & & & & & & & \\
\hline \multicolumn{8}{|c|}{ Oбране покоління $=96$} & & & \\
\hline \multirow{2}{*}{ Назвн гібррндів буряку } & \multicolumn{9}{|c|}{ Декади } & \multirow{2}{*}{ Назвн відповідної зони } \\
\hline & 1 & 2 & 3 & 4 & 5 & 6 & 7 & 8 & 9 & \\
\hline AXAT & 2693,7 & 5267,9 & 1969,5 & 7503,7 & 4464,3 & 8196,9 & 3441,6 & 8491,3 & 6639,4 & псп "Приват Агро" \\
\hline MEPAK & 0,0 & 5291,9 & 3884,4 & 11302,0 & 9314,6 & 11622,3 & 9815,9 & 2149,8 & 7398,1 & псп "Лазірки" \\
\hline ВIHЩЕН & 0,0 & 14767,9 & 4328,6 & 3236,8 & 14516,6 & 16103,4 & 16980,7 & 14645,0 & 17503,5 & ТОВ "Агрофірыа "Воровияці" \\
\hline MO3.AIK & 0,0 & 1770,5 & 27947,3 & 6093,2 & 9824,8 & 21166,3 & 32826,1 & 25808,2 & 18321,1 & СФК "Kaмina" \\
\hline PEMOC & 0,0 & 38876,6 & 34284,9 & 22368,2 & 1931,5 & 3127,0 & 28868,0 & 23043,3 & 32573,2 & фГ "Плехів Aгро" \\
\hline TIEOP & 0,0 & 3809,5 & 10350,6 & 9416,9 & 6684,8 & 6756,7 & 24702,4 & 14299,5 & 10868,8 & Стов -Україна" \\
\hline APMIIH & 0,0 & 0,0 & 63767,9 & 46578,1 & 21422,1 & 9986,9 & 26726,3 & 19370,1 & 24988,1 & СФГ "Enita" \\
\hline РОНАЛ & 0,0 & 16422,4 & 10041,0 & 706,4 & 1138,0 & 8018,0 & 17602,6 & 16449,1 & 5512,8 & ТОВ "Яромир Агро" \\
\hline ТОГАН & 0,0 & 0,0 & 51711,9 & 36789,9 & 48973,1 & 19097,3 & 53907,3 & 40034,2 & 1776,1 & СТОВ "Селецька" \\
\hline BACLIIYC & 0,0 & 0,0 & 11434,5 & 1195,1 & 22202,0 & 3123,4 & 19091,2 & 16076,3 & 16106,3 & СТОВ "Пукім'"' \\
\hline ПУШКІІ & 0,0 & 45934,7 & 36326,2 & 32665,0 & 2610,5 & 20096,6 & 28924,0 & 47989,5 & 4856,8 & СФг "O6рій" \\
\hline MAJYC & 0,0 & 21329,5 & 19481,9 & 18469,1 & 21704,0 & 2212,4 & 12386,4 & 8779,4 & 17278,5 & СTOB "Агрофipua "Друх6з" \\
\hline JILEPO & 0,0 & 3372,9 & 2902,3 & 15528,7 & 531,9 & 20189,8 & 7533,6 & 5041,7 & 8790,3 & nCП "Паяківка" \\
\hline 30.IEA & 0,0 & 4341,2 & 21239,1 & 31461,6 & 24594,0 & 24774,6 & 15580,5 & 17862,8 & 33715,7 & "Інтер-Агро" \\
\hline EEPHI & 11373,1 & 1369,7 & 5104,0 & 23711,3 & 21022,5 & 9918,2 & 4867,3 & 17208,7 & 18237,5 & СФГ "Злагода" \\
\hline ВЕДА & 24738,6 & 10780,2 & 54065,0 & 21742,7 & 35501,9 & 39102,0 & 36770,1 & 205,2 & 14147,0 & псп "Орхиця" \\
\hline BAPE.IA & 0,0 & 1079,8 & 49466,9 & 18282,1 & 34062,8 & 29099,1 & 57535,1 & 26794,5 & 24198,7 & TOB allagerw \\
\hline BABLIOB & 23387,0 & 14046,3 & 13229,9 & 8355,4 & 21209,0 & 14667,9 & 2138,8 & 3659,1 & 9265,0 & СТОВ "Агрофіриа "Зоря" \\
\hline ЯРOCJA B & 0,0 & 4052,8 & 3585,5 & 4491,9 & 22860,0 & 19251,1 & 11878,8 & 20574,0 & 19030,3 & Стов "Агрофірша "Оржицька" \\
\hline IAMAPK & 0,0 & 31662,0 & 14534,5 & 12659,7 & 33748,4 & 16363,3 & 36435,9 & 19797,9 & 31347,3 & СТОВ "Агрофірша "Куйбишева \\
\hline AKKy & 0,0 & 4658,0 & 9306,2 & 1444,0 & 4059,8 & 8764,1 & 5232,4 & 1235,5 & 7893,3 & ТОВ "Національний колорит" \\
\hline BIKTOP & 0,0 & 7249,1 & 7356,1 & 2580,6 & 420,8 & 4928,6 & 3470,0 & 9750,0 & 8059,8 & Стов "Перше травня" \\
\hline ПЕPО & 17352,3 & 19454,2 & 15330,1 & 10556,8 & 33764,5 & 17967,5 & $\mathbf{5 0 6 8 , 5}$ & 10783,7 & 12449,8 & СФГ "Свiтанок" \\
\hline $\mathrm{BOK}$ & 0,0 & 17445,3 & 15521,0 & 7987,6 & 14176,9 & 29207,0 & 16569,3 & 22595,7 & 24113,0 & ТОВ "Юнігрейн-Агро" \\
\hline ЦИЛІІІРА & 10273,4 & 8032,3 & 23086,4 & 10875,3 & 6831,2 & 3223,6 & 23622,8 & 8159,0 & 10452,3 & Arрофіриа "Aгротехнологія" \\
\hline IЕТРОЙТ & 0,0 & 0,0 & 10350,8 & 4352,8 & 10310,2 & 3489,9 & 9673,4 & 9205,3 & 8713,9 & TOB "Arpotex OBK" \\
\hline PEHOBA & 0,0 & 7803,2 & 7970,3 & 4098,4 & 9228,4 & 3859,0 & 10601,6 & 6408,5 & 958,0 & ТОВ "Вишневе агро" \\
\hline МУЛАTKA & 0,0 & 15492,4 & 15089,3 & 16240,2 & 16015,4 & 21728,2 & \begin{tabular}{|l|}
4473,7 \\
\end{tabular} & 10893,3 & 15546,8 & пП "Воронниці" \\
\hline
\end{tabular}

Рис. 2. Розклад поставок цукрових буряків на завод

При реалізації генетичного алгоритму були враховані всі пункти, сформовані у постановці задачі, а саме: обмеження та вимоги, згідно з якими мають відбуватися розрахунки, сезонність при збиранні гібридів цукрового буряка.

\section{Висновок}

1. У результаті розробки генетичного алгоритму представлено постановку задачі для складання оптимального плану поставки цукрових буряків на завод 3 урахуванням технологічних властивостей коренеплодів із різних сировинних зон.

2. Створено й оптимізовано генетичний алгоритм з урахуванням функції пристосованості.

3. Показано, що використання генетичних алгоритмів при знаходженні оптимального розв'язку задачі є доцільним, оскільки вони дають змогу враховувати специфічні особливості задачі за короткий проміжок часу.

\section{Література}

1. Вахній С.П. Продуктивність цукру буряків залежно від сортових особливостей / С.П. Вахній // Збірник наукових праць. —2008. — Випуск 10. — С. 198-201. 
2. Загоруйко В.Л. Управління постачанням цукрового виробництва / В.Л. Загоруйко, О.В. Ковальчук // Економічний форум. - 2014. - № 1. - С. 33-38.

3. Гимади Э.X. Полиномиальная разрешимость задач календарного планирования со складируемыми ресурсами и директивными сроками / Э.Х. Гимади, В.В. Залюбовский, С.В.Севастьянов // Дискретный анализ и иссследование операций. Сер. 2. - 2009. - Т. 7 , № 1. - С. 9-34.

4. Борисовский П.А. Гибридный алгоритм построения расписания многопродуктивного производства, основанный на декомпозиционном подходе и генетическом алгоритме / П.А. Борисовский, А.В. Еремеев // Материалы IV Всероссийской конференции «Проблемы ортимизации и экономические приложения». - Омск : Полигр. центр КАН, 2009. - С. 214.

5. Щоткін В. Агротехнологія вирощування цукрового буряку / В. Щоткін // Пропозиція. - 2001. - № 2. - С. 47-51.

6. Жолоб В.Д. Влияние удобрений и сроков уборки на продуктивность сахарной свеклы / В.Д. Жолоб, Е.А. Тонкаль // Селекция и агротехника - Киев : ВНИС, 1982. — С. 96-103.

7. Маковецька C.B. Дослідження та математичне моделювання процесу постачання сировини на цукровий завод 3 урахуванням генетико-детермінованих властивостей цукрових буряків / С.В.Маковецька, О.М.М'якшило, С.В.Грибков // Наукові праці Національного університету харчових технологій. - 2016. - Том 22, № 6. - С. 7-15.

8. Кормен T. Алгоритмы: построение и анализ / Т. Кормен, Ч. Лейзерсон, Р. Ривест // Пер. с англ. под ред. А. Шеня. — Москва : МЦНМО, 2002. — 96 с.

9. Безгинов А.Н. Обзор существующих методов составления расписания / А.Н. Безгинов, С.Ю. Трегубов // Информационные технологии и программирование: межвузовский сборник статей. - Москва : МГИУ, 2005. - № 2(14) - С. 5-18. 